\title{
East-West Distribution of Nutrients and Dissolved Inorganic Carbon in the Northern North Pacific in Autumn
}

\author{
Hajime Kawakami ${ }^{*}$, Makio C. Honda ${ }^{\dagger}$, Kazuhiko Matsumoto ${ }^{\dagger}$, Tetsuichi Fujiki ${ }^{\dagger}$ and \\ Shuichi Watanabe
}

Mutsu Institute for Oceanography, Japan Agency for Marine-Earth Science and Technology, 690 Aza-kitasekine Oazasekine, Mutsu, 035-0022, Japan

'Present address: Research Institute for Global Change, Japan Agency for Marine-Earth Science and Technology, 2-15 Natsushima-cho, Yokosuka, 237-0061, Japan

\begin{abstract}
We measured nutrient and dissolved inorganic carbon (DIC) concentrations from west to east across the northern North Pacific Ocean from station K2 to Ocean Station Papa during September and October 2005. At $2000 \mathrm{~m}$ depth, silicate levels increased and dissolved oxygen levels decreased from west to east. This trend was attributed to seawater in the layer flowing from west to east in the northern North Pacific. Distributions of normalized (salinity = 33) nutrients and DIC showed the general trend of "west high, east low" (WHEL) in the surface layer. Normalized nitrate and DIC concentrations above $30 \mathrm{~m}$ depth ranged from 7 to $13 \mu \mathrm{mol} \mathrm{kg}^{-1}$ and from 2027 to $2045 \mu \mathrm{mol} \mathrm{kg}^{-1}$, respectively. Seasonal drawdowns of nutrients and DIC from winter to autumn showed the WHEL trend, similar to previous studies. The ratio of silicate drawdown to nitrate + nitrite drawdown also showed the WHEL trend, which might result from longitudinal differences in the proportion of diatoms in the phytoplankton community in the northern North Pacific.
\end{abstract}

Keywords: Nutrient, dissolved inorganic carbon, northern North pacific.

\section{INTRODUCTION}

Studies of the carbon cycle have been conducted at timeseries stations in the northeastern and northwestern North Pacific Ocean to estimate the strength of the biological pump. Ocean observations have been conducted at Ocean Station Papa $\left(\mathrm{OSP} ; 50^{\circ} \mathrm{N}, 145^{\circ} \mathrm{W}\right)$ in the eastern subarctic Pacific since $1956[1,2]$. Carbon and nutrient concentrations have been measured at station KNOT $\left(44^{\circ} \mathrm{N}, 155^{\circ} \mathrm{E}\right)$ in the western subarctic Pacific since 1992 [3], and intensive timeseries observations were conducted at station KNOT between 1998 and 2000 [4]. Since 2001, we have been conducting time-series observations at station $\mathrm{K} 2\left(47^{\circ} \mathrm{N}, 160^{\circ} \mathrm{E}\right)$ in the northwestern North Pacific [5-8]. As a result of these various studies, it became clear that seasonal net community production from winter to autumn in the Western Subarctic Gyre (37-61 $\mathrm{gC} \mathrm{m}^{-2}$ [8-10]) was higher than that in the Alaska Gyre (26-35 $\mathrm{gC} \mathrm{m}^{-2}$ [2]). Spring blooms, consisting mainly of diatoms, are known to occur only in the western part of the subarctic Pacific $[11,12]$. Diatoms in this area, because of their large size and resultant high settling velocity, are suspected of playing a key role in transporting particulate organic carbon to the deep ocean [13-16].

In addition, sea surface measurements of $\mathrm{CO}_{2}$ and nutrients from commercial vessels have been made between the eastern and western North Pacific since 1995 [17, 18]. These results also indicate that the strength of the biological pump

*Address correspondence to this author at the Mutsu Institute for Oceanography, Japan Agency for Marine-Earth Science and Technology, 690 Aza-kitasekine Oaza-sekine, Mutsu, 035-0022, Japan; Tel: +81 17545 1023; Fax: +81 17545 1079; E-mail: kawakami@jamstec.go.jp in the western part of the northern North Pacific is higher than that in the eastern part. There have been many previous studies of the biological pump at each time-series station in the northern North Pacific, and the observations of sea surface $\mathrm{CO}_{2}$ and nutrient levels were previously routinely conducted from east to west across the northern North Pacific. However, simultaneous hydrographical observations of $\mathrm{CO}_{2}$ and nutrients from east to west across the northern North Pacific were never conducted during autumn when the drawdown of nutrients in the upper layer (approximately 100 $\mathrm{m})$ is at an annual maximum $[1,8]$.

In September and October 2005 we conducted biogeochemical observations across the northern North Pacific from station K2 to OSP $[19,20]$. In this paper, we present our vertical profiles of dissolved inorganic carbon (DIC) and nutrient concentrations and compare the strength of the biological pump from east to west across the northern North Pacific.

\section{SAMPLING AND ANALYSIS}

\subsection{Sampling Locations}

Observations were conducted during the cruise of $\mathrm{R} / \mathrm{V}$ Mirai in September and October 2005 in the northern North Pacific (Fig. 1). Samples were collected at stations K1 $\left(51^{\circ} \mathrm{N}, 165^{\circ} \mathrm{E}\right), \mathrm{K} 2\left(47^{\circ} \mathrm{N}, 160^{\circ} \mathrm{E}\right), \mathrm{EW} 1\left(47^{\circ} 40 \mathrm{~N}, 169^{\circ} 16 \mathrm{E}\right)$, EW2 $\left(47^{\circ} \mathrm{N}, 175^{\circ} \mathrm{E}\right)$, EW3 $\left(46^{\circ} \mathrm{N}, 180^{\circ} \mathrm{E}\right)$, EW4 $\left(46^{\circ} \mathrm{N}\right.$, $\left.175^{\circ} \mathrm{W}\right)$, EW7 $\left(49^{\circ} 30 \mathrm{~N}, 175^{\circ} \mathrm{W}\right)$, and OSP $\left(50^{\circ} \mathrm{N}, 145^{\circ} \mathrm{W}\right)$. Stations K1 and K2 are located in the northern and central parts of the Western Subarctic Gyre, respectively. OSP is located in the Alaska Gyre. 


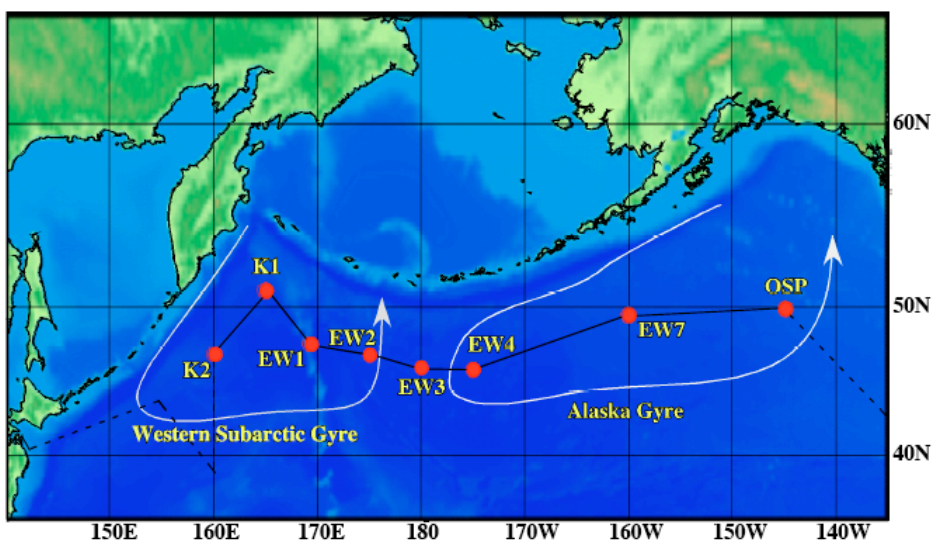

Fig. (1). Location of sampling stations and main ocean currents in the northern North Pacific Ocean. Gray lines with arrows indicate the subarctic gyres in the eastern and western regions [1].
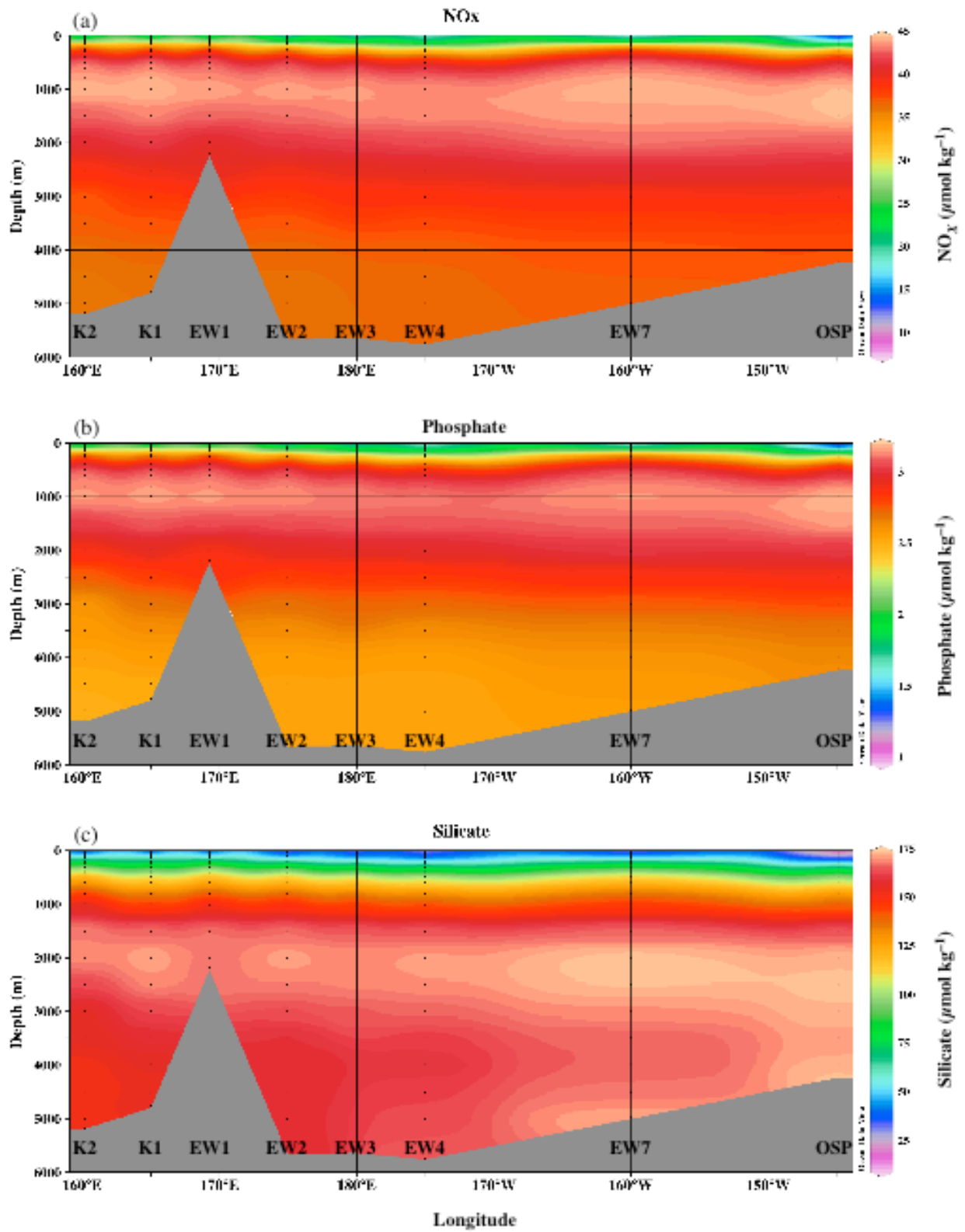

Fig. (2). Distributions of nitrate + nitrite $\left(\mathrm{NO}_{X}\right)$ (a), phosphate (b), and silicate (c) concentrations from surface to bottom in the northern North Pacific in September and October 2005. To illustrate east-west trends, data are arranged from west to east ignoring differences in latitude. Dots and gray areas indicate sampling depths and the sea floor, respectively. 


\subsection{Water Sampling and Sample Analysis}

Seawater samples were collected from the surface to the bottom layer by Niskin bottle samplers attached to a CTD (SBE 911 plus, Sea-Bird Electronics Inc.).

Nutrient concentrations were determined by using a continuous flow analyzer (TRAACS 800 system, Bran+ Luebbe). The precision $(1 \sigma)$ of nutrient analysis was less than $0.3 \%$. DIC was measured by coulometer (carbon dioxide coulometer Model 51012, UIC Inc.). The coulometer was calibrated using Dickson's certified reference material [21]. The precision $(1 \sigma)$ of DIC measurements was \pm 1.0 $\mu$ mol $\mathrm{kg}^{-1}$. Total alkalinity (TALK) was determined by potentiometric titration [22]. The precision $(1 \sigma)$ of TALK measurements was $\pm 1.3 \mu \mathrm{mol} \mathrm{kg}$. . Dissolved oxygen (DO) was analyzed by potentiometric titration [23]. The precision $(1 \sigma)$ of DO measurements was $\pm 0.05 \mu \mathrm{mol} \mathrm{kg}{ }^{-1}$. Apparent oxygen utilization (AOU) was calculated as the difference between observed DO concentration and equilibrium concentration with the atmosphere at the measured temperature and salinity [24].

\section{RESULTS AND DISCUSSION}

\subsection{Distributions of Nutrient, DIC, TALK, and DO from Surface to Bottom}

Station EW1 is located above the Emperor Seamount Chain. The bottom depth at station EW1 is approximately $2200 \mathrm{~m}$, whereas the bottom depth at the other stations range from 4200 to $5500 \mathrm{~m}$ (Fig. 2). All physical and chemical data from all stations are included in the Supplementary Material.

Nitrate plus nitrite $\left(\mathrm{NO}_{X}\right)$ and phosphate showed maximum concentrations around $1000 \mathrm{~m}$ depth across the northern North Pacific (Fig. 2a and b). We attributed the $\mathrm{NO}_{X}$ and phosphate maxima to decomposition of sinking particulate organic matter (POM). However, silicate
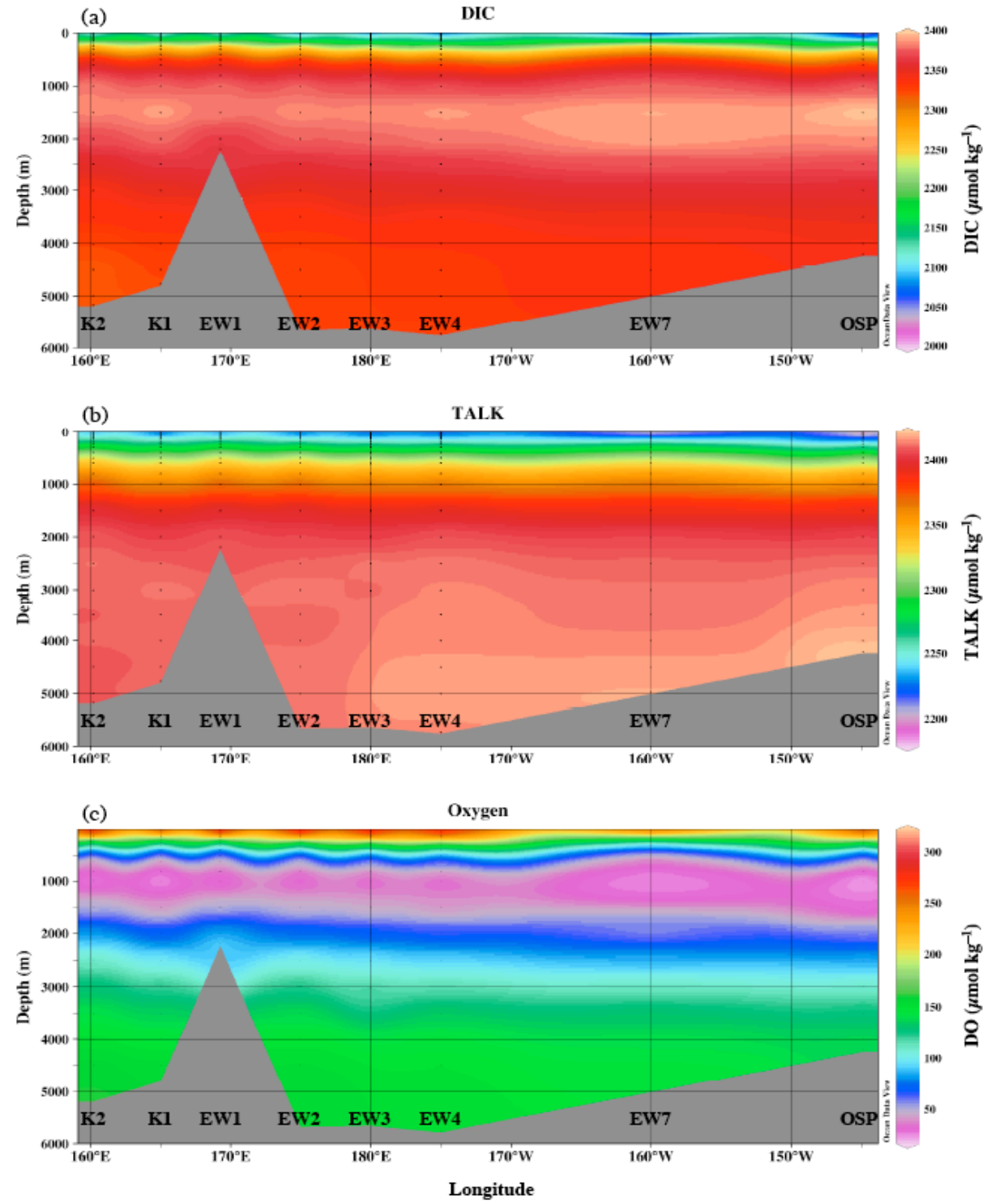

Fig. (3). Distribution of DIC (a), TALK (b), and DO (c) concentration from surface to bottom in the northern North Pacific in September and October 2005. To illustrate east-west trends, data are arranged from west to east ignoring the differences in latitude. Dots and gray areas indicate sampling depths and the sea floor, respectively. 
concentrations showed maxima from 2000 to $2500 \mathrm{~m}$ depth across the northern North Pacific and also near the bottom at stations EW7 and OSP (Fig. 2c). The silicate maximum in the intermediate layers was attributed to dissolution of sinking opal. We attributed the difference between the depth of the silicate maximum and that of the other nutrients to the different rates of decomposition for opal and other POM. The silicate maximum near the bottom at stations EW7 and OSP could be caused by dissolution of the opals from the sediment.

Maximum DIC concentrations were found at approximately $1500 \mathrm{~m}$ depth across the northern North Pacific (Fig. 3a). The DIC maximum is attributed to decomposition of sinking POM, similar to $\mathrm{NO}_{X}$ and phosphate. TALK reached the maximum levels near the bottom at stations EW7 and OSP (Fig. 3b). These TALK maxima might be caused by the dissolution of carbonates from sediment. Minimum DO concentrations were measured at approximately $1000 \mathrm{~m}$ depth (Fig. 3c). We attribute the DO minimum to the consumption of DO accompanying decomposition of the sinking POM. Therefore, the DO minimum layer coincided with the depth of maximum $\mathrm{NO}_{X}$ and phosphate concentrations (Figs. 2a, 2b, and 3c).

At $2000 \mathrm{~m}$ depth, silicate levels increased and DO levels decreased from west to east (Figs. 2c and 3c). There is significant negative correlation between silicate and DO at $2000 \mathrm{~m}(\mathrm{r}=0.89, \mathrm{P}<0.003)$. We attribute this trend to the fact that seawater at this depth in the eastern region is older than that in the western region because seawater in this layer flows from west to east in the northern North Pacific [25].

\subsection{Distributions of Physical Parameters in the Surface Layer (0-200 m)}

Potential temperature above $200 \mathrm{~m}$ depth tended to increase slightly from west to east (Fig. 4a). The potential temperature above $30 \mathrm{~m}$ depth was $10.3-11.8{ }^{\circ} \mathrm{C}$. There was clear temperature minimum layer around $100 \mathrm{~m}$ depth in the western part of the study area, and this layer became less distinct from west to east. At OSP, the temperature minimum layer was unclear and potential temperature declined with increasing depth.

Salinity above $50 \mathrm{~m}$ depth deceased slightly from west ( salinity $=32.9$ ) to east (32.4), and was lowest in the study area at station EW7 (Fig. 4b). At $150 \mathrm{~m}$, salinity at station EW7 (33.64) was higher than at the other stations $(<33.48)$.

The distribution of potential density above $30 \mathrm{~m}$ depth showed to a trend of higher values in the west and lower in the east ("west high, east low" [WHEL]; Fig. 4c). The surface mixed layer depth, defined by a criterion of a 0.125 $\mathrm{kg} \mathrm{m}^{-3}$ potential density difference from that of the surface [26], tended to increase from west (about $39 \mathrm{~m})$ to east $(50$ $\mathrm{m}$ ) in the study area (Fig. 4c). At $100 \mathrm{~m}$ depth, the potential density at OSP (25.70) was substantially lower than those at the other stations (26.14-26.58).
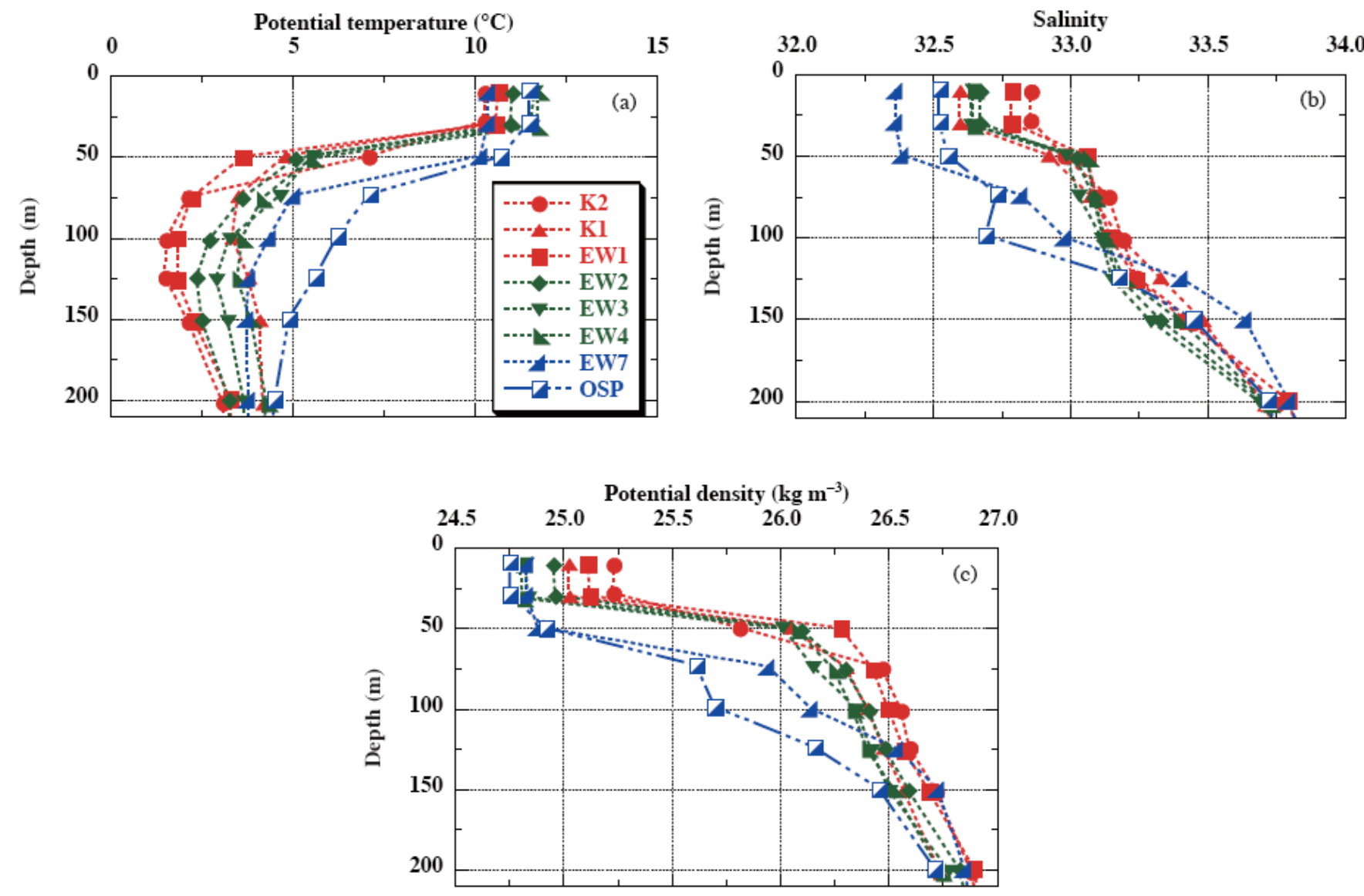

Fig. (4). Vertical distribution of potential temperature (a), salinity (b), and potential density (c) in the surface layer (10-200 m) at all stations, September-October 2005. 

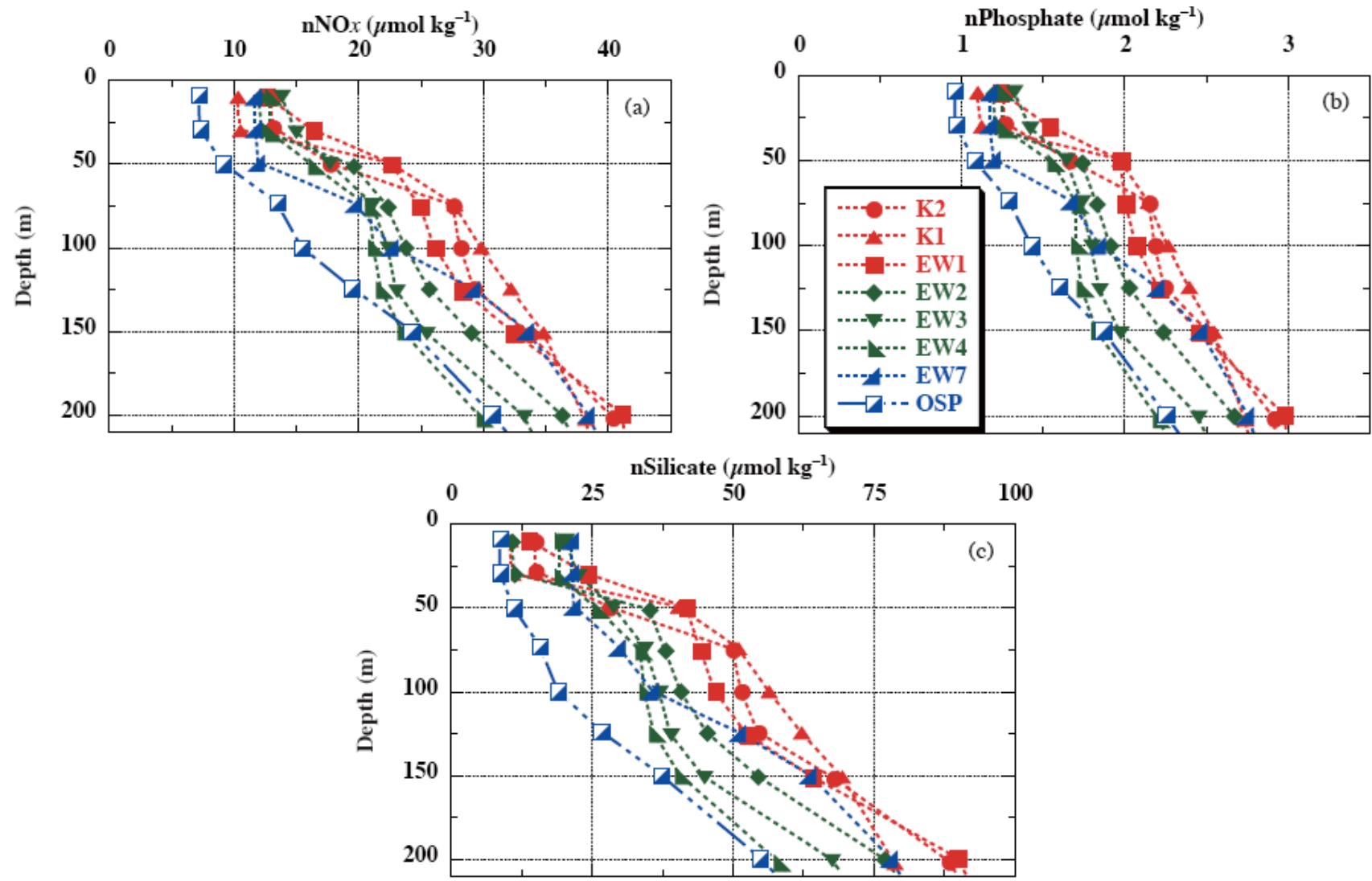

Fig. (5). Vertical distribution of normalized (to salinity of 33) $\mathrm{NO}_{X}\left(\mathrm{nNO}_{X}\right)(\mathbf{a})$, phosphate (nPhosphate) (b), and silicate (nSilicate) (c) in the surface layer (10-200 m) at all stations, September-October 2005.

\subsection{Distribution of Nutrient, DIC, TALK, DO, and AOU in the Surface Layer}

Nutrients $\left(\mathrm{NO}_{X}\right.$, phosphate, and silicate), DIC, and TALK were normalized to a constant salinity of 33 to remove the effects of evaporation and precipitation. The distribution of normalized $\mathrm{NO}_{X}\left(\mathrm{nNO}_{X}\right)$ showed the general trend of WHEL above $200 \mathrm{~m}$ depth (Fig. 5a). $\mathrm{nNO}_{X}$ above $30 \mathrm{~m}$ depth ranged from 7 to $13 \mu \mathrm{mol} \mathrm{kg}{ }^{-1}$ (Fig. 5a). At $150 \mathrm{~m}$ depth, $\mathrm{nNO}_{X}$ concentrations at stations EW3, EW4, and OSP

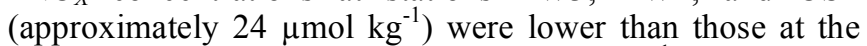
other stations (approximately $33 \mu \mathrm{mol} \mathrm{kg}{ }^{-1}$ ). The other nutrients showed similar trends (Figs. $\mathbf{5 b}$ and $\mathbf{c}$ ).
Distribution of normalized DIC (nDIC) generally followed the WHEL trend above $200 \mathrm{~m}$ depth (Fig. 6a), similar to nutrients. nDIC above $30 \mathrm{~m}$ depth ranged from 2027 to $2045 \mu \mathrm{mol} \mathrm{kg}{ }^{-1}$ (Fig. 6a). Normalized TALK (nTALK) showed vertically constant profiles at all stations (Fig. 6b).

Above $100 \mathrm{~m}$ depth, DO concentrations showed little variation with depth or between stations (Fig. 7a). Below $100 \mathrm{~m}$ depth, DO decreased with increasing depth and the differences in DO concentrations between stations were larger than those above $100 \mathrm{~m}$ depth. Values for AOU above $50 \mathrm{~m}$ depth were usually negative (i.e., water was
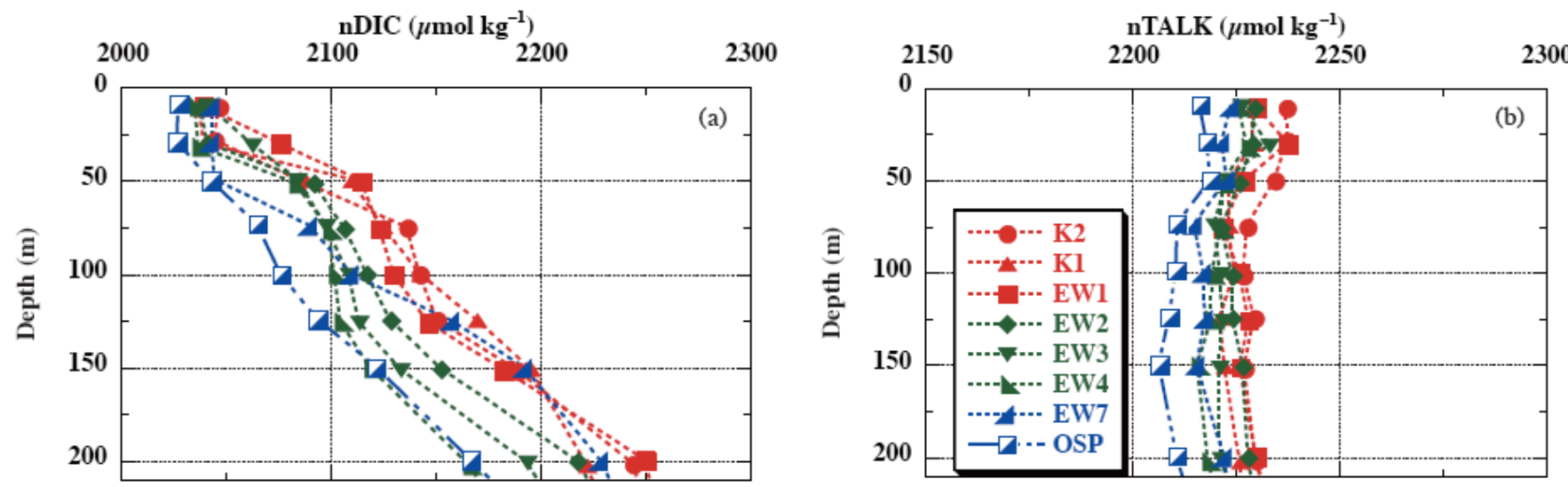

Fig. (6). Vertical distribution of normalized (to salinity of 33) DIC (nDIC) (a) and TALK (nTALK) (b) in the surface layer (10-200 m) at the all stations, September-October 2005. 

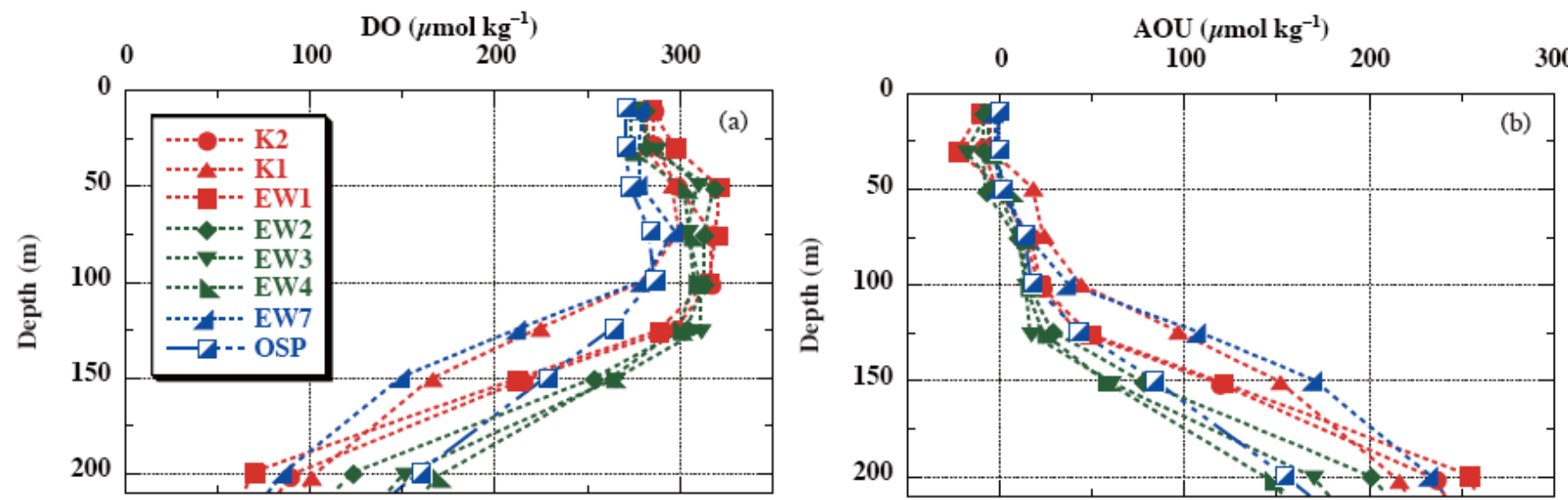

Fig. (7). Vertical distribution of dissolved oxygen (DO) (a) and apparent oxygen utilization (AOU) (b) in the surface layer (10-200 m) at all stations, September-October 2005.

supersaturated with respect to atmospheric oxygen; Fig. 7b). It is possible that these negative AOU values resulted from photosynthesis by phytoplankton. AOU increased with depth. At most stations, the rates of AOU increase with depth were different above and below $100 \mathrm{~m}$ depth. The consumption of oxygen during the remineralization of POM was apparent below $100 \mathrm{~m}$ depth.

\subsection{East-West Distributions of Seasonal Drawdown of DIC and Nutrients}

From liner regression analysis of nDIC, normalized nutrient concentrations, and AOU in the depth range of 100$200 \mathrm{~m}$ at all stations, we estimated the average regeneration ratio of $\mathrm{C}: \mathrm{N}: \mathrm{Si}: \mathrm{P}: \mathrm{O}_{2}$ at $(116 \pm 4):(16.2 \pm 0.2):(44.7 \pm$ $0.8): 1:(-172 \pm 17)$ in the northern North Pacific. The concentrations of nDIC or normalized nutrients in the surface mixed layer in winter $\left(\mathrm{A}_{\mathrm{W}}\right)$ were estimated by subtracting the regenerated fraction of each component from its concentration at $100 \mathrm{~m}\left(\mathrm{~A}_{100}\right)$ in autumn as follows [27]:

$\mathrm{A}_{\mathrm{W}}=\mathrm{A}_{100}-R_{i / O 2} \Delta \mathrm{AOU}_{100}$,

where $R_{i / O 2}$ is the regeneration ratio for each component $(i)$ and $\triangle \mathrm{AOU}_{100}$ is the difference between $\mathrm{AOU}$ at $100 \mathrm{~m}$ depth in winter and the observed AOU. AOU at $100 \mathrm{~m}$ in winter was defined as $15 \mu \mathrm{mol} \mathrm{kg} \mathrm{kg}^{-1}$ which is the average value in early April in the Western Subarctic Gyre and at OSP [8, 28].

The seasonal drawdown of DIC or nutrient concentrations in the surface mixed layer $(\Delta \mathrm{A})$ was calculated from the following equation:

$\Delta \mathrm{A}=\int_{0}^{100}\left(\mathrm{~A}_{\mathrm{W}}-\mathrm{A}_{\mathrm{Z}}\right) \mathrm{dz}$

where $\mathrm{A}_{Z}$ represents the $\mathrm{nDIC}$ or normalized nutrient concentration in each layer above $100 \mathrm{~m}$ depth. $\Delta \mathrm{A}$ represents the column-integrated drawdown of DIC or nutrients due to biological activity and/or air-sea $\mathrm{CO}_{2}$ exchange in the surface mixed layer from winter to autumn. Seasonal drawdowns were integrated from sea surface to 100 $\mathrm{m}$ depth. A depth of $100 \mathrm{~m}$ was chosen for five reasons: 1) it was close to the temperature minimum layer at most stations (Fig. 4a), 2) DO above $100 \mathrm{~m}$ depth was almost constant with depth and at all stations (Fig. 7a), 3) it was the depth reached by the mixed layer in winter $[1,8]$, 4) it was the depth at which the concentrations of DIC and nutrients were close to those at the sea surface in late winter [8, 29], and 5) decreases in DIC and nutrients from spring to autumn occurred only above $100 \mathrm{~m}$ [8, 29]. Furthermore, columnintegrated drawdowns estimated from measurements taken during this season (September and October) were considered comparable to the annual drawdowns $[1,8]$.

The trend in seasonal drawdown of nDIC and normalized nutrients $(\Delta \mathrm{C}, \Delta \mathrm{N}, \Delta \mathrm{P}$, and $\Delta \mathrm{Si})$ above $100 \mathrm{~m}$ depth from winter to autumn was generally WHEL (Figs. 8a-d). This trend is comparable with the results of previous studies [9, 17]. However, seasonal drawdowns at station EW1 were smaller than those at the neighboring stations. It is possible that the small seasonal drawdowns at station EW1 resulted from the slightly higher nDIC and normalized nutrients levels at 30-50 $\mathrm{m}$ depth at this station compared with those at the other stations (Figs. 5 and 6a). At station K2 and OSP, seasonal net community production from winter to autumn in the surface layer as estimated from $\Delta \mathrm{N}$ and the Redfield ratio (C : $\mathrm{N}=106: 16$ [30]) was 57 and $36 \mathrm{gC} \mathrm{m}^{-2}$, respectively. These results are comparable to previous values [2, 8-10].

Ratios of the seasonal drawdown of normalized silicate to that of $\mathrm{nNO}_{X}(\Delta \mathrm{Si} / \Delta \mathrm{N})$ showed the WHEL trend (Fig. 8e). Diatoms have high $\mathrm{Si} / \mathrm{N}$ ratios (1.1-3.0) [31-33], and the distribution of diatoms in the northern North Pacific follows the WHEL trend [29, 34]. In addition, dissolved iron concentrations in the surface layer in the northwestern North Pacific were nearly twice those in the northeastern North Pacific [35, 36]. Dissolved cobalt and nickel-which, like iron, are micronutrients [37]—were also found at higher concentrations in the western part of the northern North Pacific compared to the eastern part [38, 39]. Consequently, we suspected that the horizontal variations in trace metal concentrations influenced the horizontal variations in phytoplankton species composition and, further, in the strengths of the biological pump in the northern North Pacific Ocean.

\section{ACKNOWLEDGEMENTS}

We thank the captains, officers and crew of R/V Mirai for their help and support during this cruise. We also thank the marine technicians of Marine Works Japan Ltd. and 


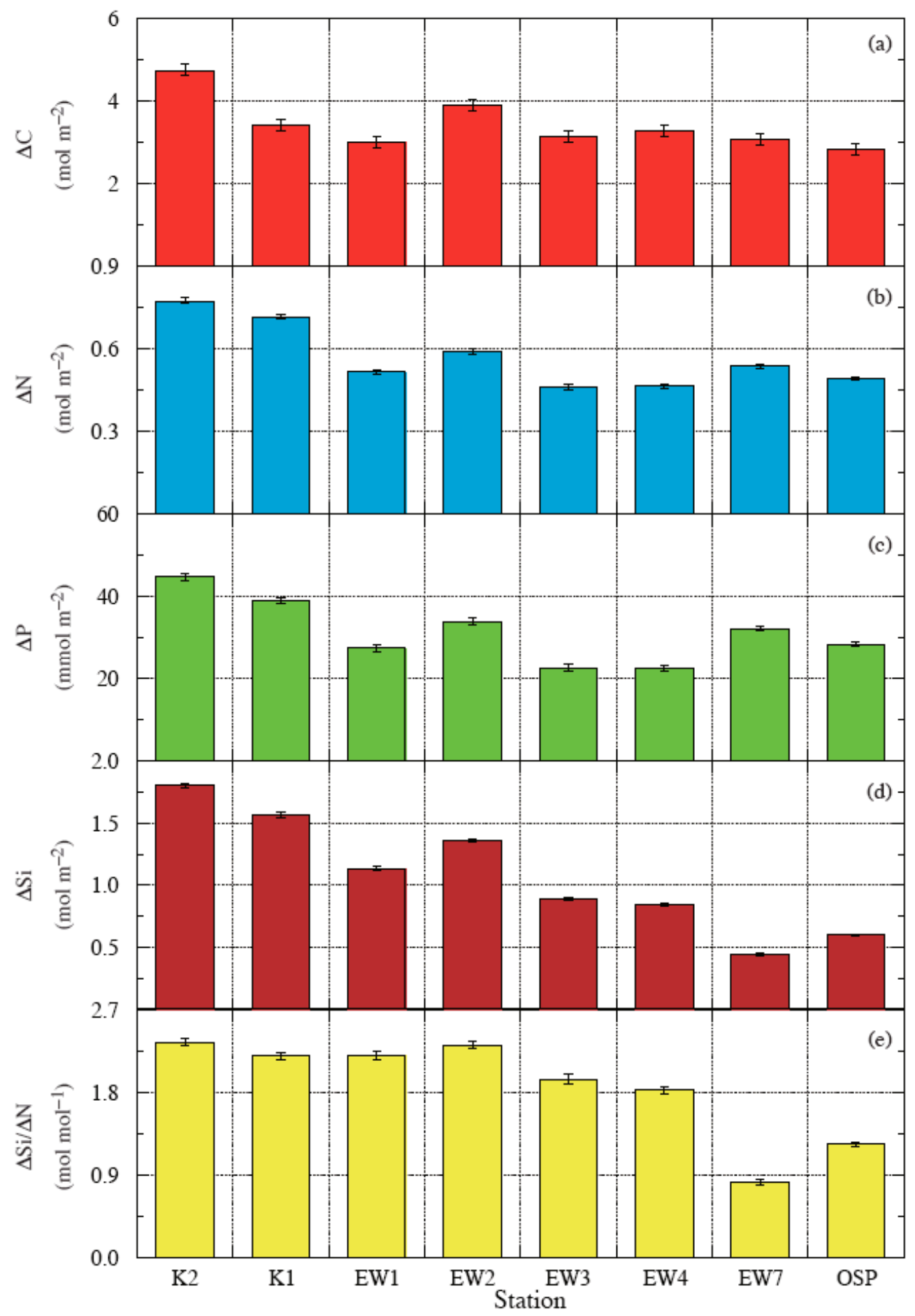

Fig. (8). East-west distributions of seasonal drawdown of DIC and nutrients $(\Delta \mathrm{C}, \Delta \mathrm{N}, \Delta \mathrm{P}$, and $\Delta \mathrm{Si})(\mathbf{a}-\mathbf{d})$ and $\Delta \mathrm{Si} / \Delta \mathrm{N}$ ratio (e) above $100 \mathrm{~m}$ depth from winter to autumn in the northern North Pacific, September-October 2005. The error bars indicate the precision $(1 \sigma)$ of each measurement.

Global Ocean Development Inc. for their on-board analysis and deck work.

\section{SUPPLEMENTARY MATERIAL}

Dataset of physical and chemical parameters at stations $\mathrm{K} 2, \mathrm{~K} 1, \mathrm{EW} 1, \mathrm{EW} 2, \mathrm{EW} 3, \mathrm{EW} 4, \mathrm{EW} 7$, and OSP in September and October 2005. The data have not been corrected for systematic errors among stations.

\section{REFERENCES}

[1] Harrison PJ, Boyd PW, Varela DE, Takeda S, Shiomoto A, Odate $\mathrm{T}$. Comparison of factors controlling phytoplankton productivity in the NE and NW subarctic Pacific gyres. Prog Oceanogr 1999; 43: 205-34.

[2] Wong CS, Waser NAD, Whitney FA, Johnson WK, Page JS. Timeseries study of the biogeochemistry of the North East subarctic Pacific: reconciliation of the $\mathrm{C}_{\text {org }} / \mathrm{N}$ remineralization and uptake ratios with the Redfield ratios. Deep-Sea Res II 2002; 49: 5717-38. 
[3] Wakita M, Watanabe S, Watanabe YW, Ono T, Tsurushima N, Tsunogai S. Temporal change of dissolved inorganic carbon in the subsurface water at station KNOT $\left(44^{\circ} \mathrm{N}, 155^{\circ} \mathrm{E}\right)$ in the western North Pacific subpolar region. J Oceanogr 2005; 61: 129-39.

[4] Saino T, Bychkov A, Chen CA, Harrison PJ. The Joint Global Ocean Flux Study in the North Pacific. Deep-Sea Res II 2002; 49: 5297-301.

[5] Honda MC, Kawakami H, Sasaoka K, Watanabe S, Dickey T. Quick transport of primary produced organic carbon to the ocean interior. Geophys Res Lett 2006; 33: 10.1029/2006GL026466.

[6] Honda MC, Watanabe S. Utility of an automatic water sampler to observe seasonal variability in nutrients and DIC in the northwestern North Pacific. J Oceanogr 2007; 63: 349-62.

[7] Kawakami H, Honda MC. Time-series observation of POC fluxes estimated from ${ }^{234} \mathrm{Th}$ in the northwestern North Pacific. Deep-Sea Res I 2007; 54: 1070-90.

[8] Kawakami H, Honda MC, Wakita M, Watanabe S. Time-series observation of dissolved inorganic carbon and nutrients in the northwestern North Pacific. J Oceanogr 2007; 63: 967-82.

[9] Tsurushima N, Nojiri Y, Imai K, Watanabe S. Seasonal variations of carbon dioxide system and nutrients in the surface mixed layer at station KNOT $\left(44^{\circ} \mathrm{N}, 155^{\circ} \mathrm{E}\right)$ in the subarctic western North Pacific. Deep-Sea Res II 2002; 49: 5377-394.

[10] Honda MC. Biological pump in northwestern North Pacific. J Oceanogr 2003; 59: 671-84.

[11] Saito H, Tsuda A, Kasai H. Nutrient and plankton dynamics in the Oyashio region of the western subarctic Pacific Ocean. Deep-Sea Res II 2002; 49: 5463-486.

[12] Yamaguchi A, Watanabe $\mathrm{Y}$, Ishida $\mathrm{H}$, et al. Structure and size distribution of plankton communities down to the greater depths in the western North Pacific Ocean. Deep-Sea Res II 2002; 49: 5513-30.

[13] Tsunogai S, Noriki S. Particulate fluxes of carbonate and organic carbon in the ocean. Is the marine biological activity working as a sink of the atmospheric carbon? Tellus 1991; 43B: 256-66.

[14] Kemp AES, Pike J, Pearce RB, Lange CB. The "Fall dump" - a new perspective on the role of a "shade flora" in the annual cycle of diatom production and export flux. Deep-Sea Res II 2000; 47: 2129-154.

[15] Smetacek VS. The giant diatom dump. Nature 2000; 406: 574-75.

[16] Honda MC, Imai K, Nojili Y, Hoshi F, Sugawara T, Kusakabe M. The biological pump in the northwestern North Pacific based on fluxes and major components of particulate matter obtained by sediment-trap experiment (1997-2000). Deep-Sea Res II 2002; 49: 5595-625.

[17] Wong CS, Waser NAD, Nojiri Y, Whitney FA, Page JS, Zeng J. Seasonal cycles of nutrients and dissolved inorganic carbon at high and mid latitudes in the North Pacific Ocean during the Skaugran cruises: determination of new production and nutrient uptake ratios. Deep-Sea Res II 2002; 49: 5317-338.

[18] Zeng J, Nojiri Y, Murphy PP, Wong CS, Fujinuma Y. A comparison of $\triangle p \mathrm{CO}_{2}$ distributions in the northern North Pacific using results from a commercial vessel in 1995-1999. Deep-Sea Res II 2002; 49: 5303-315.

[19] Fujiki T, Matsumoto K, Honda MC, Kawakami H, Watanabe S. Phytoplankton composition in the subarctic North Pacific during autumn 2005. J Plank Res 2009; 31: 179-91.

[20] Kawakami H, Honda MC, Matsumoto K, Fujiki T, Watanabe S. East-west distribution of POC fluxes estimated from ${ }^{234} \mathrm{Th}$ in the northern North Pacific in autumn. J Oceanogr; accepted.
[21] Dickson AG, Goyet C. Handbook of methods for the analysis of the various parameters of the carbon dioxide system in seawater, Version 2. 1994.

[22] Dickson AG, Afghan JD, Anderson GC, Eds. Sea water based reference materials for $\mathrm{CO}_{2}$ analysis: 2: A method for the certification of total alkalinity, unpublished, 2002.

[23] Dickson AG, Ed. Determination of dissolved oxygen in sea water by Winkler titration: WHP Operations and Methods. WHP Office Report Woods Hole, Massachusetts, USA 1994; 1-14.

[24] Weiss RF. The solubility of nitrogen, oxygen and argon in water and seawater. Deep-Sea Res 1970; 17: 721-35.

[25] Reid JL. On the total geostrophic circulation of the pacific ocean: flow patterns, tracers, and transports. Prog Oceanogr 1997; 39: 263-352.

[26] de Boyer Montégut C, Madec G, Fischer AS, Lazar A, Iudicone D. Mixed layer depth over the global ocean: An examination of profile data and a profile-based climatology. J Geophys Res 2004; 109: C12003. doi:10.1029/2004JC002378.

[27] Midorikawa T, Umeda T, Hiraishi N, et al. Estimation of seasonal net community production and air-sea $\mathrm{CO}_{2}$ flux based on the carbon budget above the temperature minimum layer in the western subarctic North Pacific. Deep-Sea Res I 2002; 49: 339-62.

[28] Steiner N, Vagle S, Denman K, McNeil C. Oxygen and nitrogen cycling in the northeast Pacific - simulations and observations at Station Papa in 2003/2004. J Mar Res 2007; 65: 441-69.

[29] Varela DE, Harrison PJ. Seasonal variability in nitrogenous nutrition of phytoplankton assemblages in the northeastern subarctic Pacific Ocean. Deep-Sea Res II 1999; 46: 2505-538.

[30] Redfield AC, Ketchum BH, Richards FA. In: Hill MH, Ed. The Sea: The influence of organisms on the composition of seawater. Wiley-Interscience, New York 1963; 26-77.

[31] Brzezinski $\mathrm{M}$. The $\mathrm{Si} / \mathrm{C} / \mathrm{N}$ ratio of marine diatoms: interspecific variability and the effect of some environmental variables. J Phycol 1985; 21:347-57.

[32] Hutchins DA, Bruland KW. Iron-limited diatom growth and $\mathrm{Si} / \mathrm{N}$ uptake ratios in a coastal upwelling regime. Nature 1998; 393: 5614.

[33] Takeda S. Influence of iron availability on nutrient consumption ratio of diatoms in oceanic waters. Nature 1998; 393: 774-7.

[34] Mochizuki M, Shiga N, Saito M, Imai K, Nojiri Y. Seasonal changes in nutrients, chlorophyll $a$ and the phytoplankton assemblage of the western subarctic gyre in the Pacific Ocean. Deep-Sea Res II 2002; 49: 5421-39.

[35] Martin JH, Gordon RM, Fitzwater SE, Broenkow WW. VERTEX: phytoplankton/iron studies in the Gulf of Alaska. Deep-Sea Res 1989; 36: 649-80.

[36] Nakabayashi S, Kusakabe M, Kuma K, Kudo I. Vertical distributions of iron (III) hydroxide solubility and dissolved iron in the northwestern North Pacific Ocean. Geophys Res Lett 2001; 28: 4611-14.

[37] Bruland KW, Donat JR, Hutchins DA. Interactive influences of bioactive trace metals on biological production in oceanic waters. Limnol Oceanogr 1991; 36: 1555-77.

[38] Fujishima Y, Ueda K, Maruo M, et al. Distribution of trace bioelements in the subarctic North Pacific and the Bering Sea (the R/V Hakuho Maru cruise KH-97-2). J Oceanogr 2001; 57: 261-73.

[39] Ezoe M, Ishita T, Kinugasa M, Lai X, Norisuye K, Sohrin Y. Distributions of dissolved and acid-dissolved bioactive trace metals in the North Pacific Ocean. Geochem J 2004; 38: 535-50. 